\title{
KEPASTIAN HUKUM TERHADAP IURAN PESERTA BPJS PASCA PUTUSAN MAHKAMAH AGUNG NOMOR 7P/HUM/2020
}

\author{
Dimas Fandhika Satria ${ }^{1 *}$, Catur Wido Haruni ${ }^{2}$, Fitria Esfandiari ${ }^{3}$ \\ ${ }^{1,2,3}$ Fakultas Hukum, Universitas Muhammadiyah Malang, Malang \\ *Koresponden: dimasfandikha70@gmail.com
}

\begin{abstract}
This study is a study of the Supreme Court's decision in responding to the application of the Indonesian Dialysis Patient Community who objected to Presidential Regulation Number 75 of 2019 which increased the contributions for BPJS participants, this study aims to find out and examine what is the basis for judges' considerations, How Judge's Decisions, as well as knowing what the legal implications of the Supreme Court Decision Number 7P/HUM/2020 are. This study uses a normative research type by approaching a judicial decision, a statutory approach, a case approach, and a conceptual approach, the types and sources of law used are divided into 3 parts, namely Primary legal materials are legislation, secondary legal materials are literature books. law, dissertations, journals, and academic manuscripts of legislation, tertiary legal materials are law dictionaries, large Indonesian language dictionaries, and Encyclopedias. The results of this study indicate that there are juridical, sociological, and philosophical aspects which are the basis for the judge's consideration in this decision. When viewed from the aspect of legal certainty, this decision emphasizes the argument of the KPCDI application which states that presidential regulation Number 75 of 2019 is contrary to Law Number 24 of 2011 concerning BPJS, and states that the Presidential Regulation is legally flawed in substance. The implication of this decision is the transfer of the judicial process to a process outside the judiciary which must be carried out using a prospective concept. The author's suggestion is that the Supreme Court Judges can examine more deeply the legal effectiveness from the perspective of BPJS, Supreme Court Judges can use the concept of Judicial Activism to avoid legal vacuums, and delegate the legal basis for BPJS in carrying out their duties and functions to the Supreme Court Decisions until the issuance of new regulations.
\end{abstract}

Keywords: Decision; Supreme Court; Material Test; BPJS

\begin{abstract}
Abstrak
Penelitian ini merupakan penelitian mengenai putusan Mahkamah Agung yang menanggapi permohonan Komunitas Pasien Cuci Darah Indonesia yang merasa keberatan dengan Peraturan Presiden Nomor 75 tahun 2019 yang menaikan iuran bagi peserta BPJS, penelitian ini bertujuan untuk mengetahui dan mengkaji apa yang menjadi dasar pertimbangan hakim, Bagaimana Putusan Hakim, serta mengetahui apa implikasi hukum atas Putusan Mahkamah Agung Nomor 7P/HUM/2020 tersebut. Penelitian ini menggunakan jenis penelitian normatif dengan melakukan pendekatan putusan peradilan, pendekatan perundang-undangan, pendekatan kasus, dan pendekatan konseptual, jenis dan sumber hukum yang digunakan dibagi menjadi 3 bagian, yaitu bahan hukum Primer adalah Perundang-undangan, bahan hukum sekunder adalah buku literatur hukum, disertasi, jurnal, dan naskah akademik perundang-undangan, bahan hukum tersier adalah kamus hukum, kamus besar bahasa Indonesia, dan Ensiklopedia. Hasil penelitian
\end{abstract}


ini menunjukan bahwa terdapat aspek yuridis, sosiologis, dan aspek filosofis yang menjadi dasar pertimbangan hakim dalam putusan ini. Jika ditinjau_aspek kepastian hukumnya putusan ini menekankan kepada dalil permohonan KPCDI yang menyatakan bahwa peraturan presiden Nomor 75 tahun 2019 bertentangan dengan Undang-undang Nomor 24 tahun 2011 tentang BPJS, serta menyatakan bahwa Peraturan Presiden tersebut cacat yuridis secara substansi. Implikasi dari putusan ini adalah pengalihan proses peradilan ke proses diluar peradilan yang harus dilakukan dengan menggunakan konsep prospektif. Saran penulis adalah Hakim Mahkamah Agung dapat mengkaji lebih dalam efektifitas hukum dari perspektif BPJS, Hakim Mahkamah Agung dapat menggunakan konsep Judicial Activism guna menghindari kekosongan hukum, serta melimpahkan dasar hukum bagi BPJS dalam melaksanakan tugas dan fungsinya kepada Putusan Mahkamah Agung sampai diterbitkannya peraturan yang baru.

\section{Kata Kunci: Putusan; Mahkamah Agung; Uji Materiil; BPJS}

\section{A. PENDAHULUAN}

Komunitas Pasien Cuci Darah Indonesia (KPCDI) mengajukan permohonan kepada Mahkamah Agung untuk dapat menguji kembali materi muatan dalam Pasal 34 Ayat (1) dan Ayat (2) Peraturan Presiden Nomot 75 tahun 2019 tentang Perubahan atas Peraturan Presiden Nomor 82 Tahun 2018 tentang Jaminan Kesehatan. Pengajuan tersebut karena menurut pemohon Peraturan Presiden tersebut memberatkan pemohon dengan alasan bahwa Jaminan Sosial yang diantaranya mencaku HAM dan salah satu unsur kesejahteraan yang harus diwujudkan sesuai dengan cita-cita Founding Father Indonesia sebagaimana termaktub dalam Undang-undang Dasar Negara Kesatuan Republik Indonesia tahun 1945 serta Peraturan tersebut dirasa tidak sesuai dengan Undang-undang Nomor 36 tahun 2009 tentang Kesehatan yang mengisyaratkan bahwa setiap individu, keluarga dan masyarakat berhak memperoleh perlindungan kesehatan dan Negara bertanggung jawab memastikan terpenuhinya hak hidup sehat bagi penduduknya, termasuk bagi masyarakat fakir miskin dan orang tidak mampu. ${ }^{1}$

Peraturan Presiden adalah salah satu Instrumen hukum dibawah undang-undang dan peraturan perundang-undangan dan dirasa tepat apabila permohonan pengujian Peraturan Presiden ini diajukan kepada Mahkamah Agung seperti yang tertuang dalam Pasal 31 Ayat (1) dan Ayat (2) Undang-undang Nomor 14 tahun 1985 tentang Mahkamah Agung maka dirasa telah memenuhi kompetensi Absolut Mahkamah Agung (Attributie Van Rechtmacht). ${ }^{2}$

Menurut Ketentuan Umum Undang-undang Nomor 12 tahun 2011 tentang Pembentukan Peraturan Perundang-undangan, peraturan presiden adalah peraturan perundang-undangan yang ditetapkan oleh Presiden untuk menjalankan perintah Peraturan Perundang-undangan yang lebih tinggi atau dalam menyelenggarakan kekuasaan pemerintahan. ${ }^{3}$ Secara hierarki, Peraturan Presiden adalah Peraturan dibawah Peraturan Pemerintah. Merujuk pada hal tersebut, maka secara materi pelaksanaan penyelenggaraan Jaminan Kesehatan Sosial haruslah merujuk kepada Peraturan Presiden Nomor 75 tahun 2019 tentang Perubahan atas Peraturan Presiden

\footnotetext{
1 “Undang-Undang Republik Indonesia Nomor 36 Tahun 2009 Tentang Kesehatan,” 2009.

2 Sholahuddin Al-Fatih, "Model Pengujian Peraturan Perundang-Undangan Satu Atap Melalui Mahkamah Konstitusi," Jurnal Ilmiah Hukum LEGALITY 25, no. 2 (July 14, 2018): 247, https://doi.org/10.22219/jihl.v25i2.6005.

${ }^{3}$ Zaka Firma Aditya and Muhammad Reza Winata, "Rekonstruksi Hierarki Peraturan Perundang-Undangan Di Indonesia (Reconstruction Of The Hierarchy Of Legislation In Indonesia)," Negara Hukum: Membangun Hukum Untuk Keadilan Dan Kesejahteraan 9, no. 1 (2018): 79-100, https://doi.org/10.22212/jnh.v9i1.976.
} 
Nomor 82 Tahun 2018 tentang Jaminan Kesehatan sebagai bentuk dari proses penjalanan kekuasaan pemerintah. BPJS adalah badan yang lahir atas Undang-Undang Jaminan Kesehatan. Artinya, bentuk pelaksanaan dari BPJS termasuk dalam tanggung jawab eksekutif.

Dalil KPCDI menyatakan bahwa Pasal 34 Ayat (1) dan (2) Peraturan Presiden Republik Indonesia tahun 2019 tentang perubahan atas Peraturan Presiden Nomor 82 tahun 2018 tentang Jaminan Kesehatan bertentangan dengan ketentuan Perundang-undangan yang lebih tinggi yaitu Pasal 2 Undang-undang Nomor 40 tahun 2004 tentang Sistem Jaminan Sosial Nasional dan Pasal 2 Undang-undang Nomor 24 tahun 2011 tentang Badan Penyelenggara Jaminan Sosial, serta menyatakan bahwa Pasal 34 Ayat (1) dan Ayat (2) Undang-undang Nomor 24 tahun 2011 tentang Badan Penyelenggara Jaminan Sosial, serta menyatakan bahwa Pasal 34 Ayat (1) dan Ayat (2) Peraturan Presiden tersebut tidak mempunyai kekuatan hukum yang mengikat.

Dalam memutus perkara tersebut, tentu Majelis Hakim di tingkatan Mahkamah Agung memiliki pertimbangan-pertimbangan yang meliputi aspek yuridis, sosiologis, dan aspek filosofis. Dalam hal ini penulis ingin lebih menitik beratkan kepenulisan ini terhadap aspek yuridis yang dipertimbangkan oleh hakim dalam memutus perkara Nomor 7P/HUM/2020 tentang Iuran Jaminan Kesehatan Nasional-Kartu Indonesia Sehat yang diselenggarakan oleh Badan Penyelenggara Jaminan Sosial serta menganalisa dan meninjau putusan Mahkamah Agung tersebut.

Dari uraian diatas penulis memfokuskan pembahasan masalah kedalam 3 (tiga) rumusan masalah untuk menghindari melebarnya pembahasan dalam penelitian yang penulis lakukan, adapun 3 (tiga) rumusan masalah tersebut sebagaimana berikut:

1. Apa dasar pertimbangan hakim dalam Putusan Mahkamah Agung Nomor 7P/HUM/2020 tentang Uji Materi Peraturan Presiden Nomor 75 tahun 2019 tentang Iuran Jaminan Kesehatan Nasional-Kartu Indonesia Sehat atas undang-undang Nomor 24 tahun 2011 tentang Badan Penyelenggara Jaminan Sosial?

2. Bagaimana aspek kepastian hukum Putusan Mahkamah Agung Nomor 7P/HUM/2020 tentang Uji Materi Peraturan Presiden Nomor 75 tahun 2019 tentang Iuran Jaminan Kesehatan Nasional-Kartu Indonesia Sehat atas undang-undang Nomor 24 tahun 2011 tentang Badan Penyelenggara Jaminan Sosial ditinjau dari aspek kepastian hukum?

3. Apa implikasi hukum atas Putusan Mahkamah Agung Nomor 7P/HUM/2020 tentang Uji Materi Peraturan Presiden Nomor 75 tahun 2019 tentang Iuran Jaminan Kesehatan Nasional-Kartu Indonesia Sehat atas Undang-undang Nomor 24 tahun 2011 ?

\section{B. METODE PENELITIAN}

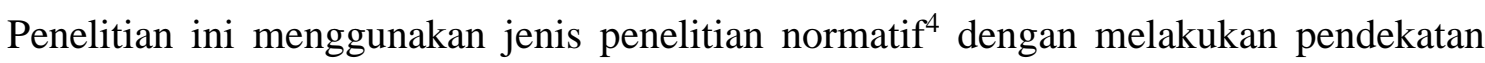
putusan peradilan, pendekatan perundang-undangan, pendekatan kasus, dan pendekatan konseptual, jenis dan sumber hukum yang digunakan dibagi menjadi 3 bagian, yaitu bahan hukum Primer adalah Perundang-undangan, bahan hukum sekunder adalah buku literatur hukum, disertasi, jurnal, dan naskah akademik perundang-undangan, bahan hukum tersier

\footnotetext{
${ }^{4}$ Irwansyah, Penelitian Hukum: Pilihan Metode \& Praktik Penulisan Artikel, ed. Ahsan Yunus (Yogyakarta: Mirra Buana Media, 2020).
} 
adalah kamus hukum, kamus besar bahasa Indonesia, dan Ensiklopedia. ${ }^{5}$ Hasil penelitian ini menunjukan bahwa terdapat aspek yuridis, sosiologis, dan aspek filosofis yang menjadi dasar pertimbangan hakim dalam putusan ini.

\section{HASIL DAN PEMBAHASAN}

\section{Dasar Pertimbangan Hakim Mahkamah Agung dalam Putusan Nomor 7P/HUM/2020 tentang Uji Materi Peraturan Presiden Nomor 75 tahun 2019 tentang Iuran Jaminan Kesehatan Nasional-Kartu Indonesia Sehat}

Dalam memutus sebuah perkara, Hakim haruslah mempertimbangkan fakta hukum yang ada ditinjau dari tiga aspek, yaitu aspek Yuridis, aspek sosiologis dan aspek filosofis. Penulis akan menganalisa ketiga aspek tersebut sebagai pertimbangan hakim dalam memutus putusan Mahkamah Agung Nomor 7P/HUM/2020 tentang Iuran Jaminan Kesehatan NasionalKartu Indonesia Sehat sebagai berikut:

\section{a. Aspek Yuridis}

Jaminan kesehatan merupakan hak asasi manusia dan salah satu unsur kesejahteraan yang harus diwujudkan sesuai dengan cita-cita Bangsa Indonesia. Oleh karena itu, negara menetapkan Sistem Jaminan Sosial Nasional bertujuan untuk memberikan kepastian perlindungan dan kesejahteraan sosial bagi seluruh rakyat Indonesia seperti yang telah diamanatkan oleh Undang-undang Dasar Negara Republik Indonesia tahun $1945^{6}$.

Untuk menjalankan Undang-undang tersebut, negara harus mengeluarkan Peraturan sebagai acuan dasar operasional penyelenggaraan Jaminan Sosial. Dalam ketentuan Pasal 4 Ayat (1) UUD 1945 menegaskan bahwa Presiden Republik Indonesia memegang tampuk kekuasaan Pemerintahan. Atas dasar ketentuan konstitusional tersebut, Presiden diberikan kewenangan untuk memutuskan (Beslissende Bevoegheid) dan mengatur (Regelende Bevoegheid). Peraturan Presiden adalah merupakan kewenangan Presiden yang bersifat mengatur yang bertujuan agar penyelenggaraan pemerintahan dapat berjalan dengan baik.

BPJS adalah badan hukum yang dibentuk untuk menyelenggarakan program jaminan sosial. ${ }^{7,8}$ BPJS bertanggungjawab kepada presiden. Organ BPJS terdiri dari Dewan Pengawas dan Direksi. ${ }^{9}$ Anggota Direksi BPJS diangkat dan diberhentikan oleh Presiden. Presiden menetapkan direktur utama, menurut Undang-undang Nomor 24 Tahun 2011 tentang Badan Penyelenggara Jaminan Sosial membentuk dua BPJS, yaitu:

1) BPJS Kesehatan, yang berfungsi menyelenggarakan program jaminan kesehatan; dan

\footnotetext{
${ }^{5}$ Johnny Ibrahim, Teori Dan Metodologi Penelitian Hukum Normatif (Malang: Bayumedia, 2007).

${ }^{6}$ Nur Islamiyah Puspasari et al., "Penyelesaian Sengketa Pembiayaan Dengan Objek Jaminan Hak Tanggungan Pada Bank Syariah Di Kota Malang,” DE LEGA LATA: Jurnal Ilmu Hukum 5, no. 1 (January 30, 2020): 24-36, https://doi.org/10.30596/dll.v5i1.3371.

7 Tedi Sudrajat, Siti Kunarti, and Abdul Aziz Nasihuddin, "Perlindungan Hukum Dan Pemenuhan Hak Pekerja Pada Program Jaminan Kesehatan Nasional,” Pandecta 15, no. 1 (2020): 83-92, https://doi.org/10.15294/pandecta.v15i1.23647.

${ }^{8}$ Putri Nur Hidayah, "Comparative Study of Legal Protection for Migrant Workers In Participation Of Social Security Programs In Indonesia And Singapore,” Legality : Jurnal Ilmiah Hukum 28, no. 1 (April 10, 2020): 47 59, https://doi.org/10.22219/ljih.v28i1.11786.

9 Alfrenso E. R. Helweldery, "Sanksi Atas Pelanggaran Terhadap Pelaksanan Jaminan Sosial Ketenagakerjaan Menurut Undang-Undang No. 24 Tahun 2011 Tentang Badan Penyelenggara Jaminan Sosial (BPJS)," Lex Et Societatis VII, no. 5 (2019): 30-37.
} 
2) BPJS Ketenagakerjaan, yang berfungsi menyelenggarakan program jaminan kecelakaan kerja, jaminan kematian, jaminan hari tua, dan jaminan pensiun.

Selain itu, Undang-undang Nomor 24 tahun 2011 tersebut juga mengatur fungsi, tugas, wewenang, dan tata kelola badan penyelenggara jaminan sosial, serta mengatur tentang tata cara pembubaran empat Persero penyelenggara jaminan sosial berikut tata cara pengalihan aset, liabilitas, hak, kewajiban, dan pegawai keempat persero kepada BPJS.

Secara mutatis mutandis kenaikan iuran bagi Peserta Pekerja Bukan Penerima Upah (PBPU) dan Peserta Bukan Pekerja (BP) sebagaimana yang diatur dalam ketentuan Pasal 34 Ayat (1) dan Ayat (2) Peraturan Presiden Nomor 75 tahun 2019 adalah ketentuan yang nyatanyata tidak sejalan dan bertentangan dengan ketentuan Pasal 2 Undang-undang Nomor 40 tahun 2011 tentang Badan Penyelenggara Jaminan Sosial yang menekankan bahwa penyelenggaraan sistem jaminan sosial nasional oleh BPJS harus berdasarkan pada asas: a. Kemanusiaan, b. Manfaat, c. Keadilan sosial bagi seluruh rakyat Indonesia. Dengan demikian, secara yuridis Pasal 34 Ayat (1) dan Ayat (2) Peraturan Presiden Nomor 2019 dinilai mengandung cacat yuridis secara substansi.

b. Aspek Sosiologis

Dalam pertimbangannya, hakim tentu haruslah melihat sepak terjang badan pengawas internal BPJS untuk dapat memahami nilai-nilai hukum dan rasa keadilan yang hidup dalam masyarakat. Hal ini dimaksudkan agar putusan hakim sesuai dengan hukum dan rasa keadilan masyarakat, oleh karena itu Mahkamah Agung memandang perlu menguraikan tentang eksistensi Dewan Jaminan Sosial dan Badan Penyelenggara Jaminan Sosial.

Anggaran BPJS kesehatan yang selalu mengalami defisit setiap tahun ${ }^{10}$ sehingga BPJS kesulitan dalam membayar utang ke Rumah Sakit sehingga mengakibatkan Rumah Sakit kesulitan juga dalam melakukan transaksi operasionalnya, seperti membeli obat, membayar dokter, dan para medis serta karyawan lainnya, membayar alat kesehatan dan sebagainya. Hal tersebut terjadi karena tata kelola kepesertaan yang tidak konsisten dalam mendata masyarakat yang seharunya ditanggung oleh pemerintah. Hal tersebut karena tidak adanya kriteria terhadap warga miskin yang seharusnya berhak mendapatkan subsidi, sehingga menyebabkan alokasi subsidi iuran menjadi tidak tepat sasaran.

Kondisi diatas setidaknya menimbulkan dampak sistemik secara langsung kepada masyarakat. Diskriminasi dalam pemberian pelayanan kesehatan kepada pasien menjadi terlihat jelas karena tidak adanya konsistensi BPJS dalam menentukan lapisan masyarakat mana yang seharusnya mendapatkan subsidi dan lapisan mana dalam masyarakat yang tidak seharusnya mendapatkan subsidi. Apabila hal tersebut dilakukan secara konsisten dan penuh kehati-hatian, defisit anggaran dana jaminan sosial seharusnya tidak sebesar seperti yang telah diproyeksikan oleh dewan jaminan sosial.

Berdasarkan uraian pertimbangan tersebut, menurut Mahkamah Agung, kesalahan dan kecurangan dalam pengelolaan dan pelaksanaan program jaminan sosial oleh BPJS yang menyebabkan terjadinya defisit dana jaminan sosial kesehatan tidak boleh dibebankan kepada masyarakat, dengan menaikan iuran bagi peserta PBPU dan Peserta BP sebagaimana diatur

\footnotetext{
${ }^{10}$ Sudrajat, Kunarti, and Nasihuddin, "Perlindungan Hukum Dan Pemenuhan Hak Pekerja Pada Program Jaminan Kesehatan Nasional.”
} 
dalam ketentuan Pasal 34 Ayat (1) dan Ayat (2) Peraturan Presiden Nomor 75 Tahun 2019. Apalagi dalam kondisi ekonomi global saat ini yang sedang tidak menentu. Kesalahan dan kecurangan pengelolaan dan pelaksanaan program jaminan sosial oleh BPJS tersebut haruslah dicarikan jalan keluar yang baik dan bijaksana dengan memperbaiki kesalahan dan kecurangan yang telah terjadi tanpa harus membebankan kepada masyarakat untuk menanggung kerugian yang telah ditimbulkan. Pembiaran terhadap kesalahan dan kecurangan yang terjadi justru pada akhirnya akan merugikan kehidupan berbangsa dan bernegara. Oleh karena itum dibutuhkan kesadaran bersama berupa kehendak politik (Political Will) dari Presiden beserta jajarannya selaku pemegang kekuasaan pemerintahan dan niat baik (Good Will) dari masyarakat dan penyelenggara program jaminan sosial untuk bersama-sama memperbaiki akar persoalan yang ada.

\section{c. Aspek Filosofis}

Dengan terbuktinya konsideran Peraturan Presiden Nomor 75 tahun 2019 yang tidak mempertimbangkan suasana kebatinan masyarakat dalam bidang ekonomi saat ini, maka dengan sendirinya ketentuan Pasal 34 ayat (1) dan (2) yang secara sepihak menaikan iuran bagi peserta PBPU dan Peserta BP guna menutupi defisit anggaran BPJS dianggap telah melanggar asas pemberian pertimbangan secara adil dan berimbang (Audi et Alterem Pertem).

Dengan demikian, pada hakikatnya kenaikan iuran BPJS sebagaimana yang diatur dalam Pasal 34 Ayat (1) dan (2) tersebut dinilai sebagai aturan yang tidak tepat dan tidak sesuai dengan tuntutan rasa keadilan masyarakat. Hal ini sejalan dengan doktrin ilmu hukum sebagaimana yang dikemukakan oleh para ahli seperti John Rawls, ${ }^{11}$ J.Stuart Mill dan Jeremy Bentham yang menegaskan pada pokoknya bahwa hukum harus berpihak kepada masyarakat tidak mampu dan harus memberikan kemanfaatan yang sebesar-besarnya kepada masyarakat terbanyak, ${ }^{12}$ sehingga penerapan Peraturan Presiden Nomor 75 tahun 2019 tidak boleh membebankan masyarakat diluar kemampuannya, melainkan justru memberikan manfaat sebesar-besarnya kepada rakyat Indonesia.

\section{Kepastian Hukum Putusan Mahkamah Agung Nomor 7P/HUM/2020 tentang Uji Materi Peraturan Presiden Nomor 75 tahun 2019 tentang Iuran Jaminan Kesehatan Nasional-Kartu Indonesia Sehat}

Untuk memberikan kepastian hukum ${ }^{13}$ kepada masyarakat dan jaminan terhadap penyelenggaraan jaminan sosial agar dapat berjalan dengan baik, Mahkamah Agung memandang perlu menguraikan akibat hukum terhadap iuran yang terlanjut telah dibayarkan sebelum ketentuan Pasal 34 Ayat (1) dan Ayat (2) Peraturan Presiden nomor 2019 dibatalkan. Hal demikian menurut Mahkamah Agung adalah menjadi otoritas pemerintah untuk mengaturnya lebih lanjut secara transparan dan bijaksana. Beranjak dari amar putusan tersebut,

\footnotetext{
${ }^{11}$ John Rawls, A Theory of Justice (Harvard University press, 1999).

12 Tata Wijayanta, “Asas Kepastian Hukum, Keadilan Dan Kemanfaatan Dalam Kaitannya Dengan Putusan Kepailitan Pengadilan Niaga,” Jurnal Dinamika Hukum 14, no. 2 (2014): 216-26, https://doi.org/10.20884/1.jdh.2014.14.2.291.

13 Mukhlishin \& Sarip, "Keadilan Dan Kepastian Hukum : Menyoal Konsep Keadilan Hukum Hans Kelsen Perspektif 'Al-,,Adl' Dalam Al-Qur'an,” Media Keadilan: Jurnal Ilmu Hukum 11, no. 1 (2020), https://doi.org/https://doi.org/10.31764/jmk.
} 
Penulis akan menguraikan inti amar putusan tersebut jika ditinjau dari aspek kepastian hukum sebagai berikut:

a. Peraturan Presiden Nomor 75 Tahun 2019 bertentangan dengan Undang-undang Nomor 24 tahun 2011 ditinjau dari aspek kepastian hukum.

Pemberian dasar hukum pelaksanaan Jaminan kesehatan nasional tersebut adalah kewenangan dari Presiden melalui Peraturan Presiden. Peraturan Presiden didasarkan pada ketentuan Pasal 4 Ayat (1) Undang-undang Dasar Negara Republik Indonesia tahun 1945 yang menegaskan bahwa Presiden Republik Indonesia memegang tampuk kekuasaan Pemerintahan menurut Undang-undang Dasar. Atas dasar ketentuan konstitusional tersebut, Presiden diberikan kewenangan untuk memutuskan (Beslissende Bevoegheid) dan mengatur (Regelende Bevoegheid). ${ }^{14}$ Peraturan Presiden merupakan kewenangan Presiden yang bersifat mengatur yang bertujuan agar penyelenggaraan pemerintahan dapat berjalan dengan baik.

Maka untuk memberikan kepastian hukum dalam memberikan jaminan sosial yang menyeluruh kepada seluruh rakyat Indonesia, dan untuk mewujudkan tujuan sistem jaminan sosial nasional sebagaimana diamanatkan dalam Undang-undang Nomor 24 Tahun 2011 tentang Badan Penyelenggara Jaminan Sosial, Presiden diberikan kewenangan untuk mengaturnya dalam hal ini menetapkan Peraturan Presiden tentang Jaminan Kesehatan, Sehingga diterbitkan Perpres Nomor 75 tahun 2019 sebagai perbaikan atas perpres sebelumnya, diantaranya Perpres Nomor 19 tahun 2016, Perpres Nomor 28 tahun 2016, yang kemudian disempurnakan melalui perpres Nomor 82 tahun 2018.

Dengan putusan Mahkamah Agung tersebut, Konsekuensi yuridis dalam kondisi ini adalah menyebabkan Pasal 34 Ayat (1) dan Ayat (2) Peraturan Presiden Nomor 75 tahun 2019 menjadi batal demi hukum (Nietig), oleh karena itu segala akibat hukum yang ditimbulkan oleh ketetapan, kebijakan dan keputusan yang didasarkan pada ketentuan tersebut dengan sendirinya dianggap tidak pernah ada (Ex Tunc).

b. Pasal 34 Ayat (1) dan Ayat (2) Peraturan Presiden Nomor 75 tahun 2019 tidak memiliki kekuatan hukum mengikat pasca putusan Mahkamah Agung Nomor 7P/HUM/2020 ditinjau dari aspek kepastian hukum.

Pasca Putusan Mahkamah Agung Nomor 7P/HUM/2020 tentang Hak Uji Materiil Peraturan Presiden Nomor 75 tahun 2019 tentang iuran Jaminan Kesehatan Nasional-Kartu Indonesia Sehat, Badan penyelenggara Jaminan Sosial tidak memiliki dasar hukum dalam menjalankan fungsinya, hal tersebut dapat dilihat dalam Amar Putusan Mahkamah Agung Nomor 7P/HUM/2020 yang dimana menyatakan bahwa Pasal 34 Ayat (1) dan Ayat (2) Peraturan Presiden Nomor 75 tahun 2019 tidak mempunyai kekuatan hukum yang mengikat.

Konsekuensi dari putusan tersebut memiliki dampak negatif bagi kepastian hukum, karena dengan tidak adanya tindakan administratif yang dilakukan oleh pemerintah untuk mencabut peraturan tersebut maka peraturan tersebut dianggap tidak memiliki kekuatan

${ }^{14}$ Sunny Ummul Firdausy and Rizal Abdurrahman, "Analisis Batasan Kewenangan Presiden Dalam Membentuk Peraturan Presiden Menurut Undang-Undang Nomor 12 Tahun 2011,” Res Publica: Jurnal Hukum Kebijakan Publik 1, no. 3 (2017): 85-98. 
hukum yang mengikat sedangkan konsep dalam Uji Materiil yang dimiliki oleh Mahkamah Agung tidak memiliki kewenangan eksekutorial. Kewenangan eksekutorial disini adalah putusan Mahkamah Agung tidak dapat dijadikan rujukan dan payung hukum bagi BPJS Kesehatan dalam melaksanakan tugasnya. Artinya, terdapat kekosongan hukum dalam operasional penarikan iuran penyelenggaraan jaminan kesehatan oleh Badan Penyelenggara jaminan Sosial. Hal tersebut berdampak kepada tidak adanya kepastian hukum dari putusan Mahkamah Agung tersebut terhadap proses penyelenggaraan jaminan sosial yang dilaksanakan oleh BPJS.

\section{Implikasi Hukum atas Putusan Mahkamah Agung Nomor 7P/HUM/2020 tentang Uji Materi Peraturan Presiden Nomor 75 tahun 2019 tentang Iuran Jaminan Kesehatan Nasional-Kartu Indonesia Sehat Terhadap Dasar Hukum Penyelenggaraan Jaminan Kesehatan}

Putusan Hakim merupakan salah satu dari hukum Negara, sebagaimana disampaikan oleh Jimly Ashiddiqie, mengatakan bahwa hukum negara adalah hukum yang ditetapkan dengan keputusan kekuasaan negara sebagai hasil dari tindakan peraturan, penetapan, atau pengadilan. Lebih lanjut menyatakan bahwa putusan itu adalah hasil dari penghakiman pengadilan. ${ }^{15}$ Maka dapat disimpulkan bahwa putusan hakim merupakan pernyataan hakim, sebagai pejabat yang berwenang dalam lingkup kekuasaan kehakiman atau pengadilan, yang dibuat dalam bentuk tertulis, dan diucapkan dalam sidang pengadilan yang terbuka untuk umum dengan tujuan untuk menyelesaikan suatu perkara.

Konsekuensi dari pengujian secara formal adalah keseluruhan isi Peraturan Perundangundangan menjadi tidak memiliki kekuatan hukum yang mengikat, sedangkan uji materil hanya beberapa ketentuan seperti pasal, ayat atau huruf. Disinggung pada sub bab sebelumnya, Dalam Pasal 6 Ayat (2) Peraturan Mahkamah Agung Nomor 1 tahun 2011 menyatakan bahwa dalam putusannya Peraturan Perundang-undangan yang dimohonkan keberatan tersebut sebagai tidak sah atau tidak berlaku untuk umum, serta memerintahkan kepada instansi yang bersangkutan untuk segera mencabutnya, dan dalam pelaksanaan putusan tersebut diatur dalam Pasal 8 ayat (2) Peraturan Mahkamah Agung Nomor 1 tahun 2011 nahwa dalam 90 hari setelah putusan Mahkamah Agung tersebut dikirim kepada Badan atau Pejabat Tata Usaha Negara yang mengeluarkan Peraturan Perundang-undangan tersebut, ternyata Pejabat yang bersangkutan tidak melaksanakan kewajibannya, demi hukum Peraturan Perundang-undangan yang bersangkutan tidak mempunyai kekuatan hukum yang mengikat.

Perihal perintah kepada instansi yang bersangkutan untuk mencabut peraturan yang sudah dibatalkan dalam tenggat waktu 90 hari merupakan konsekuensi logis ketika sebuah peraturan telah dibatalkan oleh Mahkamah Agung. Ketentuan ini merupakan bentuk penegasan tindakan administratif yang harus diambil oleh badan/pejabat yang mengeluarkan peraturan tersebut. pencabutan ini harus segera dilakukan, tanpa tindakan administratif pun peraturan yang sudah dinyatakan tidak memiliki kekuatan hukum mengikat oleh Mahkamah Agung tidak dapat lagi diberlakukan dan dijadikan rujukan.

\footnotetext{
${ }^{15}$ Jimly Asshiddiqie, Pokok-Pokok Hukum Tata Negara Pasca Reformasi (Jakarta: PT Buana Ilmu Populer, 2007).
} 
Suatu peraturan perundang-undangan atau perbuatan administrasi negara dipandang sebagai suatu yang sah sampai dinyatakan batal (dibatalkan). Adapun batalnya suatu peraturan mengacu pada konsep prospektif, atau dengan kata lain jika "tidak sah" memiliki arti bahwa dianggap tidak pernah ada Peraturan Perundang-undangan tersebut (Ex Tunc). Mengacu kepada Ketentuan Penutup Pasal 70 Undang-undang Nomor 24 tahun 2011 tentang Badan Penyelenggara Jaminan Sosial bahwa dalam melaksanakan Undang-undang ini haruslah memiliki peraturan pelaksana yang dapat menjadi acuan secara teknis BPJS Kesehatan dalam melaksanakannya. Artinya, Undang-undang ini tidak dapat dilaksanakan oleh BPJS Kesehatan ketika peraturan presiden selaku peraturan pelaksanaan dicabut atau dibatalkan oleh Mahkamah Agung.

Jika melihat Peraturan Mahkamah Agung Nomor 1 tahun 2011 dalam Pasal 6 Ayat (2) mengenai Peraturan perundang-undangan yang dimohonkan keberatan tersebut sebagai tidak sah atau tidak berlaku untuk umum, serta memerintahkan kepada instansi yang bersangkutan segera pencabutannya adalah bentuk ketegasan Mahkamah Agung untuk tidak memberlakukan Peraturan Perundang-undangan yang diputuskan tidak memiliki kekuatan hukum mengikat seperti yang tercantum dalam Amar Putusan Mahkamah Agung Nomor 7P/HUM/2020.

Peraturan Presiden menurut definisi dalam ketentuan umum Undang-undang Nomor 12 tahun 2011 tentang Pembentukan Peraturan Perundang-undangan adalah peraturan perundangundangan yang ditetapkan oleh Presiden untuk menjalankan perintah peraturan perundangundangan yang lebih tinggi atau dalam menyelenggarakan kekuasaan pemerintahan. ${ }^{16}$ Peraturan presiden dibentuk untuk menyelenggarakan pengaturan lebih lanjut perintah Undangundang atau Peraturan pemerintah secara tegas maupun tidak tegas diperintahkan pembentukannya.I Sesuai dengan apa yang sudah penulis jelaskan diatas, Demi kepastian hukum pasca putusan Mahkamah Agung Nomor 7P/HUM/2020 tentang Uji Materi Peraturan Presiden Nomor 75 tahun 2019 tentang iuran Jaminan Kesehatan Nasional-Kartu Indonesia Sehat BPJS selaku lembaga yang diberikan delegasi dari pemerintah dalam melaksanakan tugasnya tidak lagi di perbolehkan menurut hukum untuk merujuk ke Peraturan Presiden Nomor 75 tahun 2019 tersebut.

Implikasi hukum dalam Putusan Mahkamah Agung jika mengacu pada konsep prospektif, adalah pengalihan dari proses peradilan ke proses diluar peradilan. Yang dimaksud disini adalah adanya penyelarasan wewenang yang dilakukan oleh Mahkamah Agung. Sesuai dengan apa yang sudah penulis sampaikan diatas, bahwa Mahkamah Agung tidak memiliki kekuasaan eksekutorial dalam putusannya. Hak Uji Materiil Mahkamah Agung secara materi hanya untuk menguji apakah pokok permohonan yang diajukan tersebut harmonis dan tidak bertentangan dengan peraturan perundang-undangan diatasnya. Maka dalam putusannya, Mahkamah Agung memerintahkan kepada instansi yang bersangkutan yang dalam hal ini adalah kepresidenan untuk mencabut Pasal 34 Ayat (1) dan Ayat (2) Peraturan Presiden Nomor 75 tahun 2019 tentang iuran jaminan kesehatan nasional-kartu Indonesia Sehat. Wewenang untuk dapat mencabut dan mengganti dengan peraturan presiden yang baru dengan mempertimbangkan

\footnotetext{
16 Prischa Listiningrum, "Eksistensi Dan Kedudukan Peraturan Presiden Dalam Hierarki Peraturan PerundangUndangan Di Indonesia" Arena Hukum 12, no. 2 (2019): 337-55, https://doi.org/10.21776/ub.arenahukum.2019.01202.7.
} 
pertimbangan hakim Mahkamah Agung adalah Kewenangan eksekutorial yang mutlak dimiliki oleh eksekutif dalam merumuskan dan merancang peraturan presiden yang baru.

\section{PENUTUP}

\section{Kesimpulan}

a. Dasar pertimbangan hakim Mahkamah Agung dalam Putusan Mahkamah Agung Nomor 7P/HUM/2020 tentang Uji Materi Peraturan Presiden Nomor 75 tahun 2019 tentang Iuran Jaminan Kesehatan Nasional-Kartu Indonesia Sehat atas Undang-undang Nomor 24 tahun 2011 tentang Badan Penyelengara Jaminan Sosial terdapat 3 (tiga) dasar pertimbangan Hakim Mahkamah Agung yaitu: 1) Aspek Yuridis, bahwa Pasal 34 Ayat (1) dan Ayat (2) Peraturan Presiden Nomor 75 tahun 2019 tentang Iuran Jaminan Kesehatan Nasional-Kartu Indonesia Sehat bertentangan dengan Pasal 2 Undangundang Nomor 24 tahun 2011 tentang Badan Penyelenggara Jaminan Sosial. 2) Aspek Sosiologis, terdapat kecuarangan (Fraud) yang terjadi dari sisi pengelolaan oleh BPJS dan pelaksanaan program jaminan sosial oleh BPJS, serta kecuarangan dilakukan oleh oknum peserta yang mencari keuntunan keringanan iuran (mendapat subsidi), namun pembebanan defisit anggaran dilimpahkan kepada peserta PBPU dan BP secara umum. 3) Aspek Filosofis, kenaikan iuran BPJS tersebut dinilai sebagai aturan yang tidak tepat dan tidak sesuai dengan tuntutan rasa keadilan di masyarakat.

b. Putusan Mahkamah Agung Nomor 7P/HUM/2020 tentang uji materi Peraturan Presiden Nomor 75 tahun 2019 tentang Iuran Jaminan Kesehatan Nasional-Kertu Indonesia Sehat atas Undang-undang Nomor 24 tahun 2011 tentang Badan Penyelenggara Jaminan Sosial ditinjau dari aspek kepastian hukum menekankan kepada 2 (dua) permohonan dari pemohon yang dikabulkan oleh Hakim, yaitu Peraturan Presiden Nomor 7P/HUM/2020 dinyatakan bertentangan dengan Undang-undang Nomor 24 tahun 2011 tentan Badan Penyelenggara Jaminan Sosial. Secara yuridis, Peraturan Presiden tersebut dinyatakan cacat yuridis secara substansi. Dan Pasal 34 Ayat (1) dan Ayat (2) pasca putusan Mahkamah Agung Nomor 7P/HUM/2020 dinyatakan tidak memiliki kekuatan hukum yang mengikat.

c. Implikasi hukum dalam putusan Mahkamah Agung Nomor 7P/HUM/2020 tentang Uji Materi Peraturan Presiden Nomor 75 tahun 2019 tentang Iuran Jaminan Kesehatan Nasional-Kartu Indonesia Sehat atas Undang-undang Nomor 24 tahun 2011adalah pengalihan dari proses peradilan ke proses diluar peradilan. Yang harus dilakukan adalah dengan menggunakan konsep prospektif. Sehingga Pemerintah dapat mengkaji kembali Pasal 34 Ayat (1) dan Ayat (2).

\section{Saran}

a. Hakim Mahkamah Agung dapat lebih dalam mengkaji efektifitas hukum dari perspektif BPJS, Serta Hakim setidaknya mengkaji secara umum keseluruhan asas yang ada dalam Peraturan Presiden Nomor 75 tahun 2019 diluar apa yang telah di dalilkan dalam amar putusan karena pada dasarnya, keseluruhan asas yang ada adalah suatu kesatuan yang harus diterjemahkan keseluruh isi dalam Peraturan Presiden.

b. Penulis menyarankan dalam hal mencegah adanya celah kekosongan hukum seharusnya hakim dapat menggunakan konsep Judicial Activisme. Yang dimana untuk sementara 
hingga diterbitkannya peraturan yang baru atau tidak diterbitkan peraturan yang baru, Putusan Mahkamah Agung dapat dijadikan rujukan bagi BPJS untuk menjalankan penyelenggaraan Jaminan Kesehatan sebagai interpretasi Mahkamah Agung atas Undang-undang terkait.

c. Saran penulis dalam hal menggunakan konsep prospektif adalah melimpahkan dasar hukum bagi BPJS dalam melaksanakan tugas dan fungsinya kepada Putusan Mahkamah Agung sampai diterbitkannya Peraturan Presiden yang baru.

\section{E. DAFTAR PUSTAKA}

Aditya, Zaka Firma, and Muhammad Reza Winata. "Rekonstruksi Hierarki Peraturan Perundang-Undangan Di Indonesia (Reconstruction Of The Hierarchy Of Legislation In Indonesia)." Negara Hukum: Membangun Hukum Untuk Keadilan Dan Kesejahteraan 9, no. 1 (2018): 79-100. https://doi.org/10.22212/jnh.v9i1.976.

Al-Fatih, Sholahuddin. "Model Pengujian Peraturan Perundang-Undangan Satu Atap Melalui Mahkamah Konstitusi." Jurnal Ilmiah Hukum LEGALITY 25, no. 2 (July 14, 2018): 247. https://doi.org/10.22219/jihl.v25i2.6005.

Asshiddiqie, Jimly. Pokok-Pokok Hukum Tata Negara Pasca Reformasi. Jakarta: PT Buana Ilmu Populer, 2007.

Firdausy, Sunny Ummul, and Rizal Abdurrahman. "Analisis Batasan Kewenangan Presiden Dalam Membentuk Peraturan Presiden Menurut Undang-Undang Nomor 12 Tahun 2011." Res Publica: Jurnal Hukum Kebijakan Publik 1, no. 3 (2017): 85-98.

Helweldery, Alfrenso E. R. "Sanksi Atas Pelanggaran Terhadap Pelaksanan Jaminan Sosial Ketenagakerjaan Menurut Undang-Undang No. 24 Tahun 2011 Tentang Badan Penyelenggara Jaminan Sosial (BPJS)." Lex Et Societatis VII, no. 5 (2019): 30-37.

Hidayah, Putri Nur. "Comparative Study of Legal Protection for Migrant Workers In Participation Of Social Security Programs In Indonesia And Singapore." Legality : Jurnal Ilmiah Hukum 28, no. 1 (April 10, 2020): 47-59. https://doi.org/10.22219/ljih.v28i1.11786.

Ibrahim, Johnny. Teori Dan Metodologi Penelitian Hukum Normatif. Malang: Bayumedia, 2007.

Irwansyah. Penelitian Hukum: Pilihan Metode \& Praktik Penulisan Artikel. Edited by Ahsan Yunus. Yogyakarta: Mirra Buana Media, 2020.

Listiningrum, Prischa. "Eksistensi Dan Kedudukan Peraturan Presiden Dalam Hierarki Peraturan Perundang-Undangan Di Indonesia.” Arena Hukum 12, no. 2 (2019): 337-55. https://doi.org/10.21776/ub.arenahukum.2019.01202.7.

Mukhlishin \& Sarip. "Keadilan Dan Kepastian Hukum : Menyoal Konsep Keadilan Hukum Hans Kelsen Perspektif ‘Al-,,Adl' Dalam Al-Qur'an.” Media Keadilan: Jurnal Ilmu Hukum 11, no. 1 (2020). https://doi.org/https://doi.org/10.31764/jmk.

Puspasari, Nur Islamiyah, Novilia Safitri Dewik, Sinta Amipatul Aisiyah, and Nur Putri Hidayah. "Penyelesaian Sengketa Pembiayaan Dengan Objek Jaminan Hak Tanggungan Pada Bank Syariah Di Kota Malang." DE LEGA LATA: Jurnal Ilmu Hukum 5, no. 1 (January 30, 2020): 24-36. https://doi.org/10.30596/dll.v5i1.3371. 
ILREJ, Vol. 1, No. 2, Juli 2021

Rawls, John. A Theory of Justice. Harvard University press, 1999.

Sudrajat, Tedi, Siti Kunarti, and Abdul Aziz Nasihuddin. "Perlindungan Hukum Dan Pemenuhan Hak Pekerja Pada Program Jaminan Kesehatan Nasional.” Pandecta 15, no. 1 (2020): 83-92. https://doi.org/10.15294/pandecta.v15i1.23647.

“Undang-Undang Republik Indonesia Nomor 36 Tahun 2009 Tentang Kesehatan,” 2009.

Wijayanta, Tata. “Asas Kepastian Hukum, Keadilan Dan Kemanfaatan Dalam Kaitannya Dengan Putusan Kepailitan Pengadilan Niaga.” Jurnal Dinamika Hukum 14, no. 2 (2014): 216-26. https://doi.org/10.20884/1.jdh.2014.14.2.291. 